Historic, Archive Document

Do not assume content reflects current
scientific knowledge, policies, or practices. 


$$
\text { - }
$$




\section{Introducing the New Gladiolus}

\section{LAVENDER

Beautiful smoky lavender, with a silvery sheen. About the largest flowered in the so-called "blue" class.

Grows tall and vigorous, and keeps well after cutting.

Prolific and produces nice bulbs.

Glad Fans will be delighted with this handsome novelty.

One of the best of the "smokies."

Although some growers with limited stocks are asking $\$ 1.00$ and $\$ 1.25$ per bulb this year, I have rade the price as low as possible so that every lover of fine glads can get a start of it.

\section{RETAIL PRICES}

Size No. 1 bulbs _... . . . _ . 50 c each; $\$ 5.00$ per doz.

$$
\begin{aligned}
& \text { " " } 2 \text { " } \\
& \text { " } 63 \\
& \text { ، ، } 164 \\
& \text { " ، “ } \\
& \text { “ } \text { “ } 6 \\
& \text { ، ، }
\end{aligned}
$$

$30 \mathrm{c}$

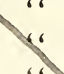

$25 \mathrm{c}$

WHOLESALE PRICES tor 19 31
Size No. 1 bulbs

$$
\text { “، }
$$

Both retail and wholesale prices include delivery.

Six bulbs will be sold at the dozen rate, and 25 or 50 at the 100 rate.

If you rwant to "put one over" on the other fellow, get this novelty; few have seen it yet.

\section{HOWARD M. GILLET, Gladiolus Specialist}

Box L, NEW LEBANON, N. Y.

My complete 36-page Retail Catalog, “THE GLADIOLUS BEAUTIFUL," containing 45 illustrations and describing 175 beautiful varieties of Gladiolus, will be mailed free on request. 


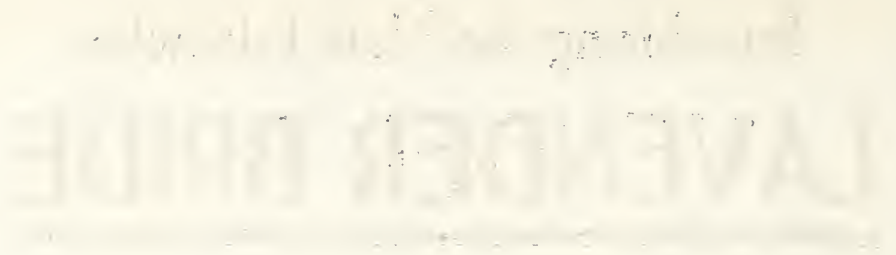

